\title{
BIBLICAL AND NON-BIBLICAL TIME PARADIGMS \\ IN EDUCATION AND ITS MULTICULTURAL ENVIRONMENT
}

\author{
Cezary Andrzej Mizia
}

\begin{abstract}
Resumé
This article describes historical-anthropological change in the education system based on territory of today's Czech Republic. It clarifies understanding of human existence and its final purpose by examining the influential strength of time paradigms. Ancient and biblical time paradigms explain the historical changes in the meaning of education. Understanding the effluence of the different ways in perceiving time paradigms helps to prevent many social conflicts and increases the effect of education in a multicultural environment.
\end{abstract}

\section{Key words}

Time paradigm, education, biblical time, ancient time, multicultural proceeding.

\section{Biblická a nebiblická paradigmata času v edukaci v multikulturním prostředí}

\begin{abstract}
Př́spěvek chce zachytit historicko-antropologickou změnu ve vnímání času v edukační praxi na území dnešní České republiky. Článek se zabývá také vlivem časových paradigmat na vnímaní lidské existence a její smysluplnosti. Časová paradigmata antického a biblického charakteru ovlivňovaly v dějinách postoje k vyučovaní. Antické termíny Chronos a Kairos spolu s lineárním a cyklickým konceptem času vysvětlují možné varianty vnímaní času ve školství. Monochromní a polychromní pojetí času specifikuje jednotlivé kultury a věkové skupiny. Pochopení rozdílů v chápání časových paradigmat napomáhá v zamezení konfliktů a zefektivnění edukace v multikulturním prostředí.
\end{abstract}

\section{Klíčová slova}

Paradigma času, edukace, čas biblický, čas antický, multikulturní přistup. 


\section{Introduction}

Ancient and biblical traditions help in understanding not only our past but also today. Education is an element of culture and as such, subsequently flexible, similar to the changeable elements of human life. Under the influence of historical events, transformations occur in political-economic systems, socio-cultural and our psychological understanding of the world. Notable is the concept of time and how its understanding creates new paradigms influencing teachers, students, as well as the comprehension of education. More and more noticeable is time paradigms impacting education in multicultural environment in the Czech Republic.

\section{Chronos and Kairos}

Like most modern languages, Czech has only one term for time. The ancient Greeks distinguished between times and used two different words: kairos and chronos, whereas Czech translation of both is consisted in one word.

It is noteworthy that each of those different words describe specific function of time. Chronos is time on the move, which means time as before and after, time as the future passing through the present. This means that the present become the past even at the moment we are thinking or speaking about the present.

In Czech language, the closest word derived from "chronos" is the word "kronika" (originally "chronika"), or the word "chronologie", which means a chronicle of events in their order of occurrence in time. The Greek chronos could be measured by the distance that exists between the events and their subsequent time. By the Greek, chronos was uncontrollable, savage and destructive. The Greek god, Chronos devoured his own offspring. ${ }^{1}$ Greeks have expressed this belief in the inexorable fulfillment of destiny, which man can not change. As with the mythological Oedipus, who killed his father and married his mother and could not do anything to escape fulfillment of prophecy.

Kairos, to distinguish from the previous, was presented as a god in the form of a young man with wings on his feet and sometimes with a razor in his hand. This symbolism expressed the transience of a moment, which is given to man. Kairos can be understood as the time or opportunity to seize in the event. ${ }^{2} \mathrm{Hu}-$ man life can be described as man's kairos placed in eternal chronos. Chronos is a measurable quantum; Kairos is a qualitative and significant form of time. It

\footnotetext{
${ }^{1}$ BURN, L. Greek Myths. (2002) pp. 11-13.

${ }^{2}$ STAFFORD, E, HERRIN, J. Personification... (2005) pp. 123-135.
} 
is an opportunity which has its importance, and in this, lays its essence. In the Christian concept, time is not empty but is filled with meaning (see: Galatians 4:4). Salvation in Christ realizes in time, and through the participation of believers in the Christian mysteries. Education is part of this concept of the divine plan of salvation, in which everything is focused and complete in Christ. Kairos can also express the temporal sequences in education such as classes, semesters and teaching hours. In the concept of Kairos, education is understood as positive. It is an opportunity to produce and experience the value and a chance to gain wisdom that students will need in their lives.

Up to the Age of Enlightenment, education was oriented on searching for Wisdom, the absolute Truth, which was God. In the territory of the Czech Republic this concept had been present almost since the arrival of the Byzantine missionaries - Saints Cyril and Methodius. ${ }^{3}$ Czech schools were founded on the Christian foundations but during the Austro-Hungarian Empire this paradigm changed. The schooling started to be devoted to prepare man for service in the hierarchical structures of the state. During this absolutist state, the time was to appoint social roles and responsibilities, which supposedly led to the grandeur of the monarchy. The modern model of education was an important factor of strengthening the state. And so, a teacher became a civil servant and students were formed (educated), in order to fulfill the role of their state best. This school concept was associated with the development of Enlightenment philosophy and was accompanied by its scientific discoveries in fields such as astronomy, physics and others. In classical Newtonian physics, time is independent from the other dimensions and runs simultaneously throughout the universe. Mechanistic physics, together with notions of time, became part of understanding the world. In this way, the Post-Enlightenment concept of time approached the ancient Chronos. At the same time, since the Roman Catholic religion was the official Austro-Hungarian ideology, Kairos remained as one of the concepts of time. Kairos even though inherited from Christian-Latin civilization was already understood more as individual and less systematic.

At the time Czechoslovakia was established, education was comprehended as a tool to strengthen national identity while still gradually becoming a priority for individual student success. The sense of individualization of education was associated with the development of liberal capitalism which meant that the individual and his interests were primary. During the First Czechoslovak Republic, the state drew from the Enlightenment era the concept of civic edu-

${ }^{3}$ See: MIKA, J. Sociální a kulturní... (2009) p. 72. 
cation, and although Christianity remained the dominant religion, it ceased to dominate as the fundamental ideology as it was in the previous period of the monarchy. Students and teachers had to find their own way and sense of existence. Structurally, the time paradigm associated with Christianity, as part of the institution of the state, lost its influence on one's finding place in the world.

In 1948 Marxist materialism overwhelmingly started to dominate Czechoslovakia using Hegelian dialectical analysis of history, where time acted as the contractor of historical necessity. The nature of the Marxist dialectical process presented a person's fate as irrelevant against the class struggle, which is the source of implementing the ideology. Education and the time paradigm were subjected to requisite incarnation of this idea at all levels of society. The totalitarian regime of the Marxist ideology of Czechoslovakia instrumented education, however, it gave students and teachers a clear historic-time paradigm. In a liberal and multicultural society this attractive environment continues to this day because it is not able to offer a sundry option. Paradoxically, new discoveries in physics with the theory of relativity did not have a major impact on time perception in education. Today the Newtonian concept of time in understanding of the Greek chronos dominates. Time is the fourth dimension of space-forming by the theory of relativity and its passing depends on the observer, so it differs by every observer. The modern concept of time is mostly suited to the concept of Kairos which regards merciless Chronos and stresses the subjective nature of events. From the modern physics viewpoint, describing hours spend at schools, a word "chronotopic" education curriculum should be used because it would emphasizes the subjective and spatial-semantic nature of time.

\section{Cyclical and linear time paradigm}

One of the oldest and also the basic time paradigms is the cyclical concept of time. It is connected with the determinism view of world history and human life. Cyclically repeated bouts of life come from the observation of natural cycles, where there is a recurrence of the seasons and phases of life and especially the reproductive cycle. To this day the cyclic conceptions of time are dominant and remain in the cultural environments under the influence of Hinduism, Buddhism and New Age. Traced from the time of ancient Greece and Rome and also in European civilization, this concept has its place. Later this dominant way of thinking was replaced by the Christian Roman Empire with the biblical concept of linear time. Cyclical time paradigm is best presented in the classic Greek drama of Odysseus. After a long battle in Troy, and innumerable 
obstacles Odysseus returned to his native island of Ithaca. The fate of a man is locked in a time circle filled with a predetermined scenario. Man in this drama of gods, and humans, is determined not only to a time circle, but also to a role which he has to play. In the ontological and ethical sense, a-person-a-mask plays his role well when he compels what is in man's essence ${ }^{4}$. Here time presents a factor that is plastic: it can flow slowly or quickly, it is subjectively perceived as Kairos - it is a given time so a person can fulfill its role.

The other time paradigm is the linear concept of time. This concept is understood as the result of biblical revelation and is linked with human freedom and uniqueness of life. The Judeo-Christian tradition symbolizes a history of a person as on a road. The linear narrative is the consequence of unique events. During the travel on that road, a person is placed not only in front of the dramatic nature of life's facts, but also the drama of choices to make, which changes a person's fate over time ${ }^{5}$. The classical linear history is the way of Abraham to the Promised Land (cf. Genesis 12-22). Abraham, who could not find the meaning of life in a relatively stable environment of Uhr Chaldean, decided to set out on a risky journey into the unknown. Abraham was on the road, but did not know exactly where he was going. The road is a dialogue, during which Abraham knew that the fulfillment of the meaning of pilgrimage, during his lifetime was perhaps more important than achieving a specific objective 6 .

Odysseus' story ended up with him coming back home. Abraham's story is a pilgrimage to the hometown to which he will never return. In this time paradigm, people's events are somehow similar to each other because they follow the nature of living on earth, but in fact, happen only once, uniquely, and so are important. In time, human decisions influence not only the history of individual lives but also affect the fate of others, therefore, every decision carries an enormous responsibility. The ancient gods and later God of the biblical revelation are not indifferent to the drama of people on the world stage. In the biblical sense, human time is the time of salvation. God is the master of time as well as the master of history. Since the dramatic events arise here and now, time paradigm has to answer questions that people ask today in these particular circumstances. A person's life is radically unique and individual one, and if it is desired, that life does not become a parody of the "drama", a circus; it must exceed space and time so as to be more than a string of political, economic, or social events. ${ }^{7}$

${ }^{4}$ See: BARTNIK, CZ-S. Personalizm. (2000) pp. 71-72.

${ }^{5}$ GOLDFAJN, T. Word order and time... (1999) pp. 34-39.

${ }^{6}$ WILSON, M. R. Our Father Abraham... (1989) pp. 159-162.

${ }^{7}$ PIOTROWSKI, E. Teodramat. (1999) pp. 29-30. 
Christian concept of time contains both, an element of the experience of Abraham which is the linear path, and the Greek concept of the cyclically recurring elements of time. The uniqueness of it is expressed in both responsibility for the acts and the cyclicality of many similar simultaneous events. This is particularly visible with the establishment of the liturgical cycle. Christian life began to take place within a time limit of Advent until the next season of Advent. The main event of this annual cycle is Easter followed by liturgical periods such as Christmas, Lent and regular time. When Christianity became the soul of the Roman Empire, in a sense, schooling began to copy the series. Education began to take place between major holidays. The time from autumn until Christmas formed the first part; second part of the school year began after Christmas and ended on the Holy Trinity and Corpus Christi holidays, followed by school break. In this way following the natural cycle of nature, the education cycle gained its spirituality.

In the concept of time the First Republic of Czechoslovakia followed the historically inherited cycle of continued schooling. However, there has been a fundamental change due to an opposition to Catholicism, understood as part of Austro-Hungarian domination. This opposition had led to a time paradigm shift in education. The previous linear-cyclical model with Abraham, exemplified in saints, has been replaced by historical-linear model, with an indication of national heroes such as Jan Hus, Jan Žižka, and Jan Amos Komenský. The salvation telos was replaced with the welfare of the nation and the state. ${ }^{8}$ The transcendent purpose suddenly became immanent, time lost its biblical - linear form. What was left from the Christian liturgy cycle was the remnant of cyclically repeated civilian school year. Although the majority of the population of the First Republic of Czechoslovakia continuously recognized Christian values, but its education system had already given a clearly definable sense of life and the knowledge gained in schools served more utilitarian functions, separated from seeking the absolute Truth.

\section{Cultural - psychological aspects of time}

One of the important elements detailing a specific culture is its understanding of time. To some extent time paradigms determine the behavior of individuals and groups. In the Czech culture, similarly to the Western European students, they identify their existence by the "real life" time where they are free from school and responsibilities.

${ }_{8}^{8}$ PUTNA, M, C. Česká katolická literatura... (1998) pp. 588-592. 
After completing their education, students then carry this style to their workplace. The most common goal of education is graduation in a utilitarian understanding of it, not so as to gain knowledge and wisdom. Students seek to accelerate the sequences of educational time and slow down the susceptive time to "feel that they live". Time devoted to activities that make no sense is experienced as lasting a long time. The susceptive phase of time is understood as pleasant or unpleasant, going together with time devoted to required activities and those of leisure.

One well-known psychological phenomenon is that children perceive the passage of time slower than adults. Small children understand time as a course of individual sequences. Initially these sequences are just satisfactions of physiological needs. Then they take a form of pleasant and unpleasant events. The perception of time is dependent not only on the actual turnout, but also its intensity. Day, week, month and year in the schooling years are marked by events connected with schooling. The multiplicity of changes and the uniqueness of these years mean that education time elapses relatively slowly. The uniqueness is also connected with a student's promotion, and accompanying changes in mental and physical development. The quantum for children, for instance, the time in class requires concentration combined with abstract thinking; children feel it as unending. Naturally, smaller children have difficulty with focusing on one subject for a long period of time, to allow re-concentration their "hour" should be shortened, or at least arranged to short sequences. ${ }^{9}$

It is known that young children understand time as present and can not imagine a distant one, even in relatively near future. Waiting time always seems extraordinary long. Children as well as adults do not plan their futures. They do not wonder what they will be doing next week, month, year. Depending on the culture, adults can experience their psychological time as directed towards the future, past or present. ${ }^{10}$ For example, the Africans live mainly in the present, which is the result of cultural and social experiences. The future is unknown, so it is uncertain, and therefore does not need to take place. In the Czech culture, adults tend to live in the future "until the children finish their school; until we have saved for it; until we have more time for it..." Getting older comes together with the internal psychological retrospective of time.

Many cultural differences can be explained by monochromatic and polychrome time recognitions. The polychrome explains that time becomes very

\footnotetext{
${ }^{9}$ MONTANGERO, J; CATTIN, J-P. Understanding changes in time... (1996) pp. 6-19.

${ }^{10}$ See: ONTANGERO, J; CATTIN, J-P. Understanding changes in time... (1996) pp. 6-19.
} 
flexible, events could be accelerated and decelerated, and could change priorities. The basis of this perception of time is its flexibility and improvisation, but unfortunately also it is associated with unpunctuality and not keeping up terms. The monochromatic perception is characterized by precise planning of time, punctuality and reliability, but also a little flexibility. In this case, events can not be sped up or slowed down. Overall, the nations of Northern Europe and North America understand time as a physical fact, with its material value of "time is money". There, a man may lose time, win, distribute, or schedule it. Time as an element of education determines not only the stages of learning, but may be converted into concrete gains in terms of achieving graduation, license, title, etc. To the nations of southern Europe, America and Africa, time is in the service of man. In these cultures, people are less abided by time and use it more for their own good. Through education, people profit and achieve social recognition.

Education systems increasingly encounter problems with multicultural groups. People living together with different time paradigms have problems with understanding each other. They produce negative stereotypes. Cultural differences can create misunderstandings in teacher-student relations. Generally, fifteen-minute late time limit is not considered a serious offense by students from southern cultures. The nations perceiving time as a intermittently flowing factor, social gatherings can last much longer than in the Czech environment where such excessively long gatherings are considered a waste of time.

In education, time specifically understood in different cultures requires a multicultural approach. The primary task is to understand the existing culture and the communication language which generate requirements of expressing symbols and paradigms understandable to that culture. Educational systems by their nature standardize requirements for all individuals and groups, they cannot adapt easily to the minorities without detriment to the majority. One solution would be for the individuals and groups to adapt to the education systems of countries in which they live. The other option would be an education system directed towards mutual appreciation of the differences that come from different cultures' time paradigms.

\section{Conclusions}

Time understanding is strongly linked to cultures and cultural values and is reflected in all aspects of life. Education in the Czech Republic has undergone a long evolution, which is reflected in substantial changes in time paradigms. Today's education lacks an integral concept of meaning and of substance recog- 
nizing existence as a whole, in which individual sequences of time are anchored to the linear paradigm with a clearly defined transcendent purpose. Diverse cultures experience time in different, specific ways. A multicultural environment needs to be reflected in education and possible adoption of emerging time paradigms.

\section{References}

BARTNIK, C. S. Personalizm. $1^{\text {st }}$ ed. Lublin: „O.K.“ Tomasz Wiater, 2000, 531 pp. ISBN 83-913771-0-5.

BURN, L. Greek Myths. $1^{\text {st }}$ ed. Bath: Sith University of Texas Press, 2002, 80 pp. ISBN 0-292-72748-8.

GOLDFAJN, T. Word order and time in Biblical Hebrew narrative. $1^{\text {st }}$ ed. New York: Oxford University Press, 1998, 169 pp. ISBN 0-19-826953-6.

MIKA, J. Sociální a kulturní souvislostí geneze vzdělávání dospělých-andragogiky. In: Acta Humanica. 2009, no. 3, pp. 71-74. ISSN 1336-5126.

MONTANGERO, J.; CATTIN, J.-P. Understanding changes in time: the development of diachronic thinking in 7 to 12 year old Children. $1^{\text {st }}$ ed. Abingdon: Taylor\&Francis, 1996, 195 pp. ISBN 0-7484-0470-8.

PIOTROWSKI, E. Teodramat. Dramatyczna soteriologia Hansa Ursa von Balthasara. $1^{\text {st }}$ ed. Kraków: WAM, 1999, 355 pp. ISBN 83-7097-500-3.

PUTNA, M. C. Česká katolická literatura 1848-1918. $1^{\text {st }}$ ed. Praha: Torst, 1998, 801 pp. ISBN 80-7215-059-6.

STAFFORD, E., HERRIN, J. Personification in the Greek World: from Antiquity to Byzantium. Centre for Hellenic Studies, King 's College London Publications no. 7. $1^{\text {st }}$ ed. Aldershot: Ashgate, 2005, 376 pp. ISBN 0-7546-5031-6.

WILSON, M. R. Our Father Abraham: Jewish Roots of the Christian Faith. $1^{\text {st }}$ ed. Grand Rapid-Dayton: Wm. B. Eerdmans Publishing Com. Center for JudaicChristian Studies, 1989, 338 pp. ISBN 0-8028-0423-3.

\section{Contact address:}

Th.Lic. Cezary Andrzej Mizia,

Dr. Slezská univerzita v Opavě,

Obchodně podnikatelská fakulta v Karviné, katedra společenských věd,

Univerzitní náměstí 1934/3,

73340 Karviná,

Tel: 00420596398 266, Fax: 00420596312069. 